\title{
Diagnosis of the Causes of the Rain Flooding in June in the West Africa Coastal Area
}

\author{
Joël Amouin ${ }^{1,2 *}$, Kouassi Yves Kouadio ${ }^{1 *}$, Modeste Kacou ${ }^{1}$, Sandrine Djakouré1, Samuel Ta ${ }^{1}$ \\ ${ }^{1}$ Laboratory of Matter, Environmental and Solar Energy Sciences (LASMES), Ocean-Atmosphere Interaction Group, University \\ F.H.B. of Cocody Abidjan, Abidjan, Côte d'Ivoire \\ ${ }^{2}$ Abidjan Meteorological Center of the Agency for the Safety of Air Navigation in Africa and Madagascar (ASECNA), Abidjan, \\ Côte d'Ivoire \\ Email: ^amouinjoel@gmail.com, ^yves.kouadio@gmail.com
}

How to cite this paper: Amouin, J., Kouadio, K.Y., Kacou, M., Djakouré, S. and Ta, S. (2021) Diagnosis of the Causes of the Rain Flooding in June in the West Africa Coastal Area. Atmospheric and Climate Sciences, 11, 11-31.

https://doi.org/10.4236/acs.2021.111002

Received: September 4, 2020

Accepted: November 30, 2020

Published: December 3, 2020

Copyright (c) 2021 by author(s) and Scientific Research Publishing Inc. This work is licensed under the Creative Commons Attribution International License (CC BY 4.0).

http://creativecommons.org/licenses/by/4.0/

\section{Open Access}

\begin{abstract}
Rain flooding during June on the West Africa coastal area is analyzed by using the 95th and 75th percentiles, which represent extreme and intense rainfall events respectively. Thus, the contribution of these events that reaches around 50\% shows their impact on the rainfall in June. Atmospheric and oceanic factors influence the rain flooding. Indeed, the extreme events are associated with easterly waves propagating from $20^{\circ} \mathrm{E}$, while those of intense events are initiated around $5^{\circ} \mathrm{E}$. The impact of oceanic conditions exhibits the warming of the equatorial rail and the Atlantic cold tongue, the warming of the whole ocean basin and a north-south dipole of SST anomalies. The West African monsoon that reaches Abidjan corresponds to a low-level atmospheric flow, whose upward motion extends in latitude from the ocean to the continent. An increase of disturbance contributes to enhancing these events. This is confirmed by the inflow on to the continent of oceanic moisture coming from the ventilation by evaporation of warm water. In addition, the coupled ocean-atmosphere simulations are one of the best candidates that could help to better explain these dramatic events. This study is useful because of showing solutions that could help in adoption of policies for the risks management related to these events.
\end{abstract}

\section{Keywords}

West Africa Coast, Rain Flooding, Threshold, Atmospheric and Ocean Surface Conditions

\section{Introduction}

Côte d'Ivoire is located in West Africa, on the edge of the tropical Atlantic 
Ocean, between $9^{\circ} \mathrm{W}-2.5^{\circ} \mathrm{W}$ longitude and $4^{\circ} \mathrm{N}-11^{\circ} \mathrm{N}$ latitude. Its area is $322,462 \mathrm{~km}^{2}$ and the population is around 23.7 million according to the latest 2014 census carried out by the "Institut National de la Statistique" (http://www.ins.ci/n/). This country is influenced by humid air masses (hereafter monsoon) from May to September, the seasonal migration of the InterTropical Convergence Zone (hereafter ITCZ) and dry air masses (hereafter harmattan) from December to March. Thus, Côte d'Ivoire has experienced climatic fluctuations marked by severe droughts, as an example those of 1983 and 1994 which had significant social and economic impacts [1], with increasing wildfires, the loss of some cash crops and lower yields of food crops. Moreover, this region has undergone exceptional rainfall in 1968 and 1984 [2], and 1987 [3] which had negative social and economic impacts.

Abidjan $\left(4.013^{\circ} \mathrm{W} ; 5.3^{\circ} \mathrm{N}\right)$ is the economic capital of Côte d'Ivoire. It is the country's largest metropolis with an area of $2119 \mathrm{~km}^{2}, 10$ municipalities and 4.395 million inhabitants. This metropolis concentrates on the main economic and industrial activities of the country. In the last two decades, it has suffered disastrous social and economic consequences due to the rainfall intensification during the rainy season, and particularly in June which is the core of this season. For example, the ONU-HABITAT [4] report indicated that floods and landslides due to heavy rains were the main risks of natural disasters leading to loss of life and destruction of homes, especially those most at risk. This is in agreement with the "Société d'Exploitation et de Développement Aéroportuaire, Aéronautique et Météorologique" (hereafter SODEXAM) rain gauges measurements, which mentioned an exceptional rainfall amount $(302.3 \mathrm{~mm})$ during the night of June $18^{\text {th }}$ to June $19^{\text {th }} 2018$, only in the municipality of Cocody (Table 1 ). Indeed, this amount represented about half of the rainfall in June. Therefore, many damages were observed such as around 18 deaths and 120 injuries, a flood and a landslide in the district of Abidjan (https://news.abidjan.net/h/639829.html). The frequent floods observed in recent times are therefore due to the exceptional quality of rainfall. However, ONU-HABITAT [4] also points out the occupation of roads and facilities of public interest, the city extension that does not match with the objectives of the urban planning and master plan for development which is never updating.

The disastrous consequences of these rainfall events require an understanding of their interannual variability and the influence of ocean and atmospheric conditions. Several studies have notably suggested a relationship between Atlantic Ocean conditions and rainfall in West Africa [2] [5] [6] [7], and relationship between both oceanic and atmospheric conditions and extreme rainfall [8]. Ta et al. [8] showed, for example, a different influence of oceanic and atmospheric conditions in the tropical Atlantic on the extreme rainfall in each of the climate zones of West Africa. Lafore et al. [9] also studied the oceanic and atmospheric conditions during an extreme rainfall event that occurred in 2009 in Ouagadougou (Burkina Faso) in the Sahel. Thus, they showed that the sea surface temperature (SST) anomalies observed in the Atlantic cold tongue, in the Atlantic 
Table 1. Historical data of rain flooding events at Abidjan and the corresponding damages in June during the 2007-2018 period. Rainfall amount is recorded by rain gauge at each municipality.

\begin{tabular}{|c|c|c|c|}
\hline Date & Municipality & $\begin{array}{l}\text { Human damages/Type of } \\
\text { disaster/Property damage }\end{array}$ & $\begin{array}{l}\text { Rainfall amount } \\
\text { at a municipality }\end{array}$ \\
\hline 05 June 2007 & $\begin{array}{l}\text { Yopougon, } \\
\text { Attécoubé }\end{array}$ & $\begin{array}{c}9 \mathrm{dead} / \text { Floods and } \\
\text { landslides/Submerged } \\
\text { road, House destroyed }\end{array}$ & $71.4 \mathrm{~mm}$ at port Bouët \\
\hline 29 June 2008 & Cocody & $\begin{array}{c}7 \text { dead, }>20 \text { injured and several } \\
\text { displaced persons/Floods/Houses } \\
\text { destroyed }\end{array}$ & $49.6 \mathrm{~mm}$ at port Bouët \\
\hline 11 June 2009 & $\begin{array}{c}\text { All the } \\
\text { municipalities }\end{array}$ & $\begin{array}{c}22 \text { dead, } 6 \text { missing, } 7 \text { injured, } \\
48 \text { families and } 121 \text { students } \\
\text { homeless/Floods and } \\
\text { landslides/Destruction of house and } \\
\text { submerged road, Traffic interrupted }\end{array}$ & $105.0 \mathrm{~mm}$ at port Bouët \\
\hline 24 June 2010 & $\begin{array}{l}\text { Cocody, } \\
\text { Adjamé, } \\
\text { Abobo }\end{array}$ & $\begin{array}{l}13 \text { dead/Floods and } \\
\text { landslides/Destruction of house and } \\
\text { submerged road, Traffic interrupted }\end{array}$ & $65.4 \mathrm{~mm}$ at port Bouët \\
\hline 16 June 2011 & $\begin{array}{l}\text { Abobo, } \\
\text { Attécoubé }\end{array}$ & $\begin{array}{l}09 \mathrm{dead} / \text { Floods and } \\
\text { landslides/Destruction of house }\end{array}$ & $\begin{array}{l}\text { Closed } \\
\text { station }\end{array}$ \\
\hline 23 June 2011 & $\begin{array}{l}\text { Attécoubé, } \\
\text { Cocody }\end{array}$ & $\begin{array}{c}06 \mathrm{dead} / \text { Floods and } \\
\text { landslides/Destruction of house }\end{array}$ & $\begin{array}{l}\text { Closed } \\
\text { station }\end{array}$ \\
\hline 05 June 2014 & $\begin{array}{l}\text { Attécoubé, } \\
\text { Cocody }\end{array}$ & $\begin{array}{c}6 \mathrm{dead} / \text { Floods and } \\
\text { landslides/Destruction of house } \\
\text { and submerged road }\end{array}$ & $\begin{array}{c}86 \mathrm{~mm} \\
\text { at plateau }\end{array}$ \\
\hline 18 June 2014 & $\begin{array}{l}\text { Cocody, } \\
\text { Attécoubé }\end{array}$ & 12 dead/A collapsed building & $\begin{array}{l}153 \mathrm{~m} \text { at Songon, } \\
122 \mathrm{~mm} \text { at plateau }\end{array}$ \\
\hline 28 June 2014 & Cocody & $\begin{array}{c}\text { Loss of life/Floods/Stormwater } \\
\text { rise to } 2 \mathrm{~m} \text {, habitat destruction, } \\
\text { traffic disrupted }\end{array}$ & $\begin{array}{l}145 \mathrm{~mm} \text { at plateau, } \\
108.9 \mathrm{~mm} \text { at Marcory }\end{array}$ \\
\hline 10 June 2017 & $\begin{array}{l}\text { Attécoubé, } \\
\text { Yopougon }\end{array}$ & $\begin{array}{c}3 \text { dead, } 1 \text { missing/Floods } \\
\text { and landslides/Wall collapse, } \\
48 \text { houses destroyed }\end{array}$ & $\begin{array}{l}245.3 \mathrm{~mm} \text { at Attécoubé, } \\
190.5 \mathrm{~mm} \text { at Yopougon }\end{array}$ \\
\hline 24 June 2017 & $\begin{array}{l}\text { Attécoubé, } \\
\text { Yopougon, } \\
\text { Cocody }\end{array}$ & $\begin{array}{c}20 \text { dead, } 43 \text { injured/>100 } \\
\text { destroyed houses }\end{array}$ & $107 \mathrm{~mm}$ at Yopougon \\
\hline 03 June 2018 & $\begin{array}{l}\text { Cocody, } \\
\text { Abobo }\end{array}$ & $\begin{array}{l}01 \mathrm{dead} / \text { Floods/House } \\
\text { flooded; traffic interrupted }\end{array}$ & $\begin{array}{c}102.2 \mathrm{~mm} \\
\text { (station not shown) }\end{array}$ \\
\hline 19 June 2018 & $\begin{array}{l}\text { Cocody, } \\
\text { Yopougon, } \\
\text { Attécoubé, } \\
\text { Adjamé, } \\
\text { Abobo }\end{array}$ & $\begin{array}{c}18 \text { dead, } 120 \text { injured, several } \\
\text { people displaced or } \\
\text { homeless/Vehicles washed out, } \\
\text { House flooded, Road flooded }\end{array}$ & $302.3 \mathrm{~mm}$ at Cocody \\
\hline
\end{tabular}

dipole and in the Mediterranean Sea are favorable conditions for a stronger penetration of the African monsoon.

Most of the studies that link these dramatic rainfall events to oceanic and atmospheric conditions were generally focused on all of West Africa [10], or on 
the Sahel [9] [11], but few on the Gulf of Guinea coast [12]. The main purpose of this present work is to better understand the oceanic and atmospheric conditions that can influence the occurrence of these events with disastrous consequences for the economy and social life of this booming city on the West African coast. Such study is important to propose solutions that could allow the adoption of adequate policies for the management of risks related to these events, and particularly to civil protection and urban planning. Section 2 presents the data and methods used in this study. Section 3 discusses the results by analyzing observed rainfall events and their relationships with oceanic and atmospheric conditions in the tropical Atlantic. Finally, a conclusion is given in the last section.

\section{Data and Methods}

\subsection{Data}

June is the core of the rainy season in southern Côte d'Ivoire, especially in Abidjan. It is the month in which the city experiences heavy flooding. The history of these rain flooding events and the damages that occurred in specific municipalities of Abidjan were recorded by SODEXAM for each month of June during the 2007-2018 period. During this period, SODEXAM observed 13 events throughout the city of Abidjan in eight years (2007, 2008, 2009, 2010, 2011, 2014, 2017 and 2018) (Table 1). This corresponds to about 1.6 events per year. Table 1 includes the municipality affected by the rain flooding event, the rainfall amount recorded by a rain gauge at a specific station, the types of disasters that occurred as a consequence of the event such as the human and material damages.

The largest number of events ( 3 events) was observed in June 2014. It is noticed two events for these specific years 2011, 2017 and 2018, while only one event occurred during the years 2007, 2008, 2009 and 2010. The strongest rainfall event was recorded in eight hours on the night of June 18-19, 2018 with $302.3 \mathrm{~mm}$ only in the municipality of Cocody. During this short daily period, the most affected municipalities were Cocody, Yopougon, Attécoubé, Adjamé and Abobo (https://news.abidjan.net/h/639829.html). The weakest rainfall event was recorded on June 29, 2008 with $49.6 \mathrm{~mm}$ in the municipality of Port-Bouët. It caused seven deaths, about 20 injured and several displaced people.

When looking at the amount (Table 1), the rainfall concerns only specific measuring points and not the whole city of Abidjan. Moreover, some measurements are not accessible because they have not been carried out or they are expensive. To capture the whole study area, daily data from the Global Precipitation Climatology Project-GPCP [13] were used with $1^{\circ} \times 1^{\circ}$ resolution. These data are derived from a combination of in-situ data and microwave measurements, and are suitable for an analysis of the temporal and spatial evolution of rainfall. Indeed, a comparative analysis of 10 satellite products over the Sahelian region of West Africa [14] shows that GPCP data are better than others. The GPCP data are more representative of longer duration and better reproduce extreme events with a behavior close to the reference data [14]. In comparison, the 
TRMM 3B42 and GSMaP-MVK satellite products have a large percentage of low rainfall event grid points of less than $5 \mathrm{~mm}$ with a maximum around $20 \mathrm{~mm}$. According to Roca et al. [15], satellite data differ also considerably when they compared 10-day rainfall cumulative from rain gauges and estimates from satellite products. The results highlighted that, for the estimated errors in satellite, GPCP have a better spatial distribution of rainfall with lower errors in the central Sahel, and in the coastal region of West Africa [14]. For this study, GPCP daily rainfall for each month of June from 2007 to 2018 ( 12 years, i.e. $~ 360$ values) was extracted for Abidjan.

The analysis of the causes of these rain flooding events is carried out by using daily data of sea surface temperature (SST), vertical and horizontal winds and specific humidity. Sea surface conditions are derived from Reynolds data [16] over the tropical Atlantic and are extracted from the IRI/LDEO Climate Data Library (http://iridl.ldeo.columbia.edu/). These data are in a regular grid of $1^{\circ} \times$ $1^{\circ}$ for each month of June from 2007 to 2018 . Vertical and horizontal winds, and specific humidity are extracted from the National Center for Environmental Prediction-National Center for Atmospheric Research (NCEP-NCAR) reanalysis for the same period [17]. These last data are in a $2.5^{\circ} \times 2.5^{\circ}$ grid, with 17 pressure levels from $1000 \mathrm{hPa}$ to $10 \mathrm{hPa}$ for horizontal and vertical winds, and eight pressure levels from $1000 \mathrm{hPa}$ to $300 \mathrm{hPa}$ for specific humidity.

To assess the impact of moisture transport from the lower and upper layers of the atmosphere [18] on the occurrence of these rain flooding events, the integrated vertical moisture flux transport is calculated. The zonal and meridian components of the integrated vertical moisture flux transport are derived from the specific humidity, and the zonal and meridian components of the horizontal wind on both $1000-700 \mathrm{hPa}$ and $700-300 \mathrm{hPa}$ layers.

\subsection{Methods}

The interannual variability of the rainfall events that caused flooding is studied by using the 75th and 95th percentiles. Indeed, the Expert Team on Climate Change Detection and Index Study and the users of climate data have defined extreme precipitation using the 75th, 95th and 99th percentiles [19]. So, the 95th and 75th percentiles will be used to represent extreme and intense rainfall events respectively. Both thresholds are widely used in various studies at global, regional and local scales [20] [21] [22] [23].

These two thresholds are calculated on all the values ( $\sim 360$ values) for June during the 2007-2018 period. These estimates will allow evaluating the contribution of rainfall above these thresholds and which could or could not cause flooding. In addition, the methodology of Cao et al. [23] is used to avoid overlapping of the studied events. It stipulates that a unit of \pm 5 is applied to the percentile threshold. In our case, if the value of a selected event with the 75th percentile (hereafter intense event) falls within the range defined for the 95th percentile (hereafter extreme event), then it is classified as an extreme event. Similarly, if an event belongs to the range defined for the 75th percentile or is greater 
than it, but does not fall within the range defined for the 95th percentile, then it is classified as an intense event.

According to Burpee [24] and Zhang et al. [25], Côte d'Ivoire is located in zones C2 and D bordering the tropical Atlantic (see Figure 4 in [26]). These areas are influenced by the monsoon flow from the ocean. Diawara et al. [26] noted that this influence could vary from year-to-year. The impact of the West African monsoon on rain flooding events is studied by using the methodology described by Diawara et al. [26] and Ta et al. [8]. The June meridian wind reanalysis from NCEP-NCAR [17] is used to perform this work. At a point close to the coordinates of Abidjan, the daily atmospheric level reached by the monsoon flow coming from the Atlantic Ocean (from south to north) is determined when the meridian wind changes sign from positive (oceanic flow) to negative (continental flow).

The meridian gradient of absolute vorticity $\left(\partial \zeta_{a} / \partial y\right)$, where $\zeta_{a}$ is the absolute vorticity, is calculated [27] [28] to determine areas of atmospheric instability over West Africa that follow the Charney and Stern [29] criterion. Molinari et al. [28] used the meridian gradient of absolute vorticity instead of potential vorticity over Central America. They justified this method by the weak monsoon flow in the eastern Pacific and the presence of mountains that create a diurnal fluctuation in potential vorticity. It is used here to define preferential zones of instability, instead of the potential vorticity that defines two zones of negative values south of the equator and positive values north of the equator.

\section{Results and Discussion}

\subsection{Analysis of Rainfall Events}

Figure 1 illustrates the interannual evolution of the June rainfall during the 2007-2018 period. It also shows the interannual evolution of the cumulative rainfall events above the 75th and the 95th percentile thresholds.

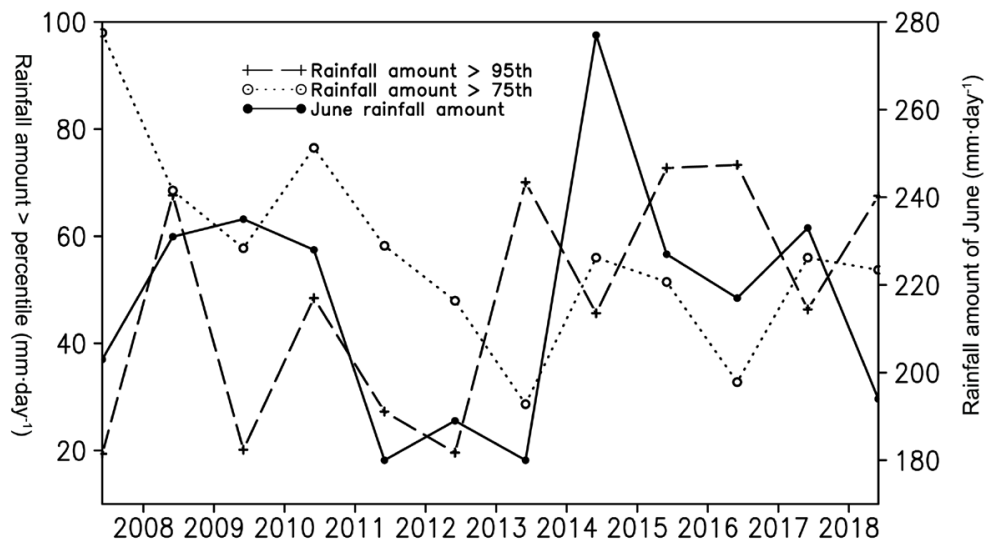

Figure 1. Interannual GPCP rainfall amount $\left(\mathrm{mm} \cdot \mathrm{day}^{-1}\right)$ of June at Abidjan from 2007 to 2018 (solid line). Interannual GPCP rainfall amount of events great to the 95th (cross and dashed line) and the 75th (open circle and dotted line) percentile thresholds are also plotted. 
An upward trend of rainfall is observed from 2013 to 2018, after a downward trend from 2007 to 2012. Rainfall above the 75th percentile shows a decreasing trend, while that above the 95th percentile has an increasing trend. This could mean a resurgence and an intensification of extreme events over the city of $\mathrm{Ab}$ idjan, as pointed out by several authors [8] for the West African coast.

During the 2007-2018 period ( $\sim 12$ years, or 360 values), 25 events are extreme, while 57 events are intense. So, there are approximately 2 events per year on average (respectively 5 per year) which are above the 95 th (respectively 75 th) percentile; that means 2.5 times more intense events than extreme events. The contribution of extreme rainfall amounts (respectively intense) represents $\sim 22.23 \%$ (respectively $\sim 26.36 \%$ ) of the cumulative rainfall amounts in June during the 2007-2018 period. The sum of these two contributions $(\sim 48.59 \%$, i.e. almost 50\%) highlights the importance of intense and extreme events in the June rainfall at Abidjan. Particularly, the low number of extreme events ( 2 per year) above the 95th percentile is likely to produce about $\sim 1 / 5$ of the June rainfall. This indicates at least a large part of the rainfall of this month is concentrated in the occurrence of a few rainy events which can have disastrous consequences for this city.

The next paragraphs and sections now focus on the rainfall events recorded by SODEXAM as being rain flooding events that caused material and human damage (see Table 1). Figure 2 presents the time series and daily anomalies of June rainfall in Abidjan during the years when flooding events were recorded by SODEXAM. Anomalies are calculated as the difference between the rainfall on a calendar day in June and the annual average for that day over the entire 2007-2018 period. The contribution (in percentage) of a given event occurring in a given month, relative to the cumulative precipitation for that month is represented, as well as the 75th and 95th percentile thresholds calculated over the entire 2007-2018 period.

Extreme events contribution ranges between 11.18\% (June 19, 2018) and $29.11 \%$ (June 29,2008 ) of the monthly cumulative, while that of intense events is lesser than $7 \%$ (Figure 2). When considering these values and the number of extreme events per year in June ( $\sim 2$ events), it seems that the total contribution of extreme events causing flooding does not exceed $\sim 30 \%$. For example, the sum of the contributions of the extreme events $(\sim 29.36 \%)$ is the largest in 2014 because only this year presents two extreme events. Similarly, this figure shows that events classified as extreme have anomalies greater than $+10 \mathrm{~mm}$, while those classified as intense have anomalies less than $10 \mathrm{~mm}$. This result is in agreement with the works of Liebman et al. [30] and Kouadio et al. [31] who used this anomaly threshold for heavy rains over Northeast Brazil. In the case of intense events, the anomalies are either negative or slightly positive and in most cases below $5 \mathrm{~mm}$.

\subsection{Impact of the Monsoon Depth}

Figure 3 shows the daily climatology of the mean atmospheric depth calculated 

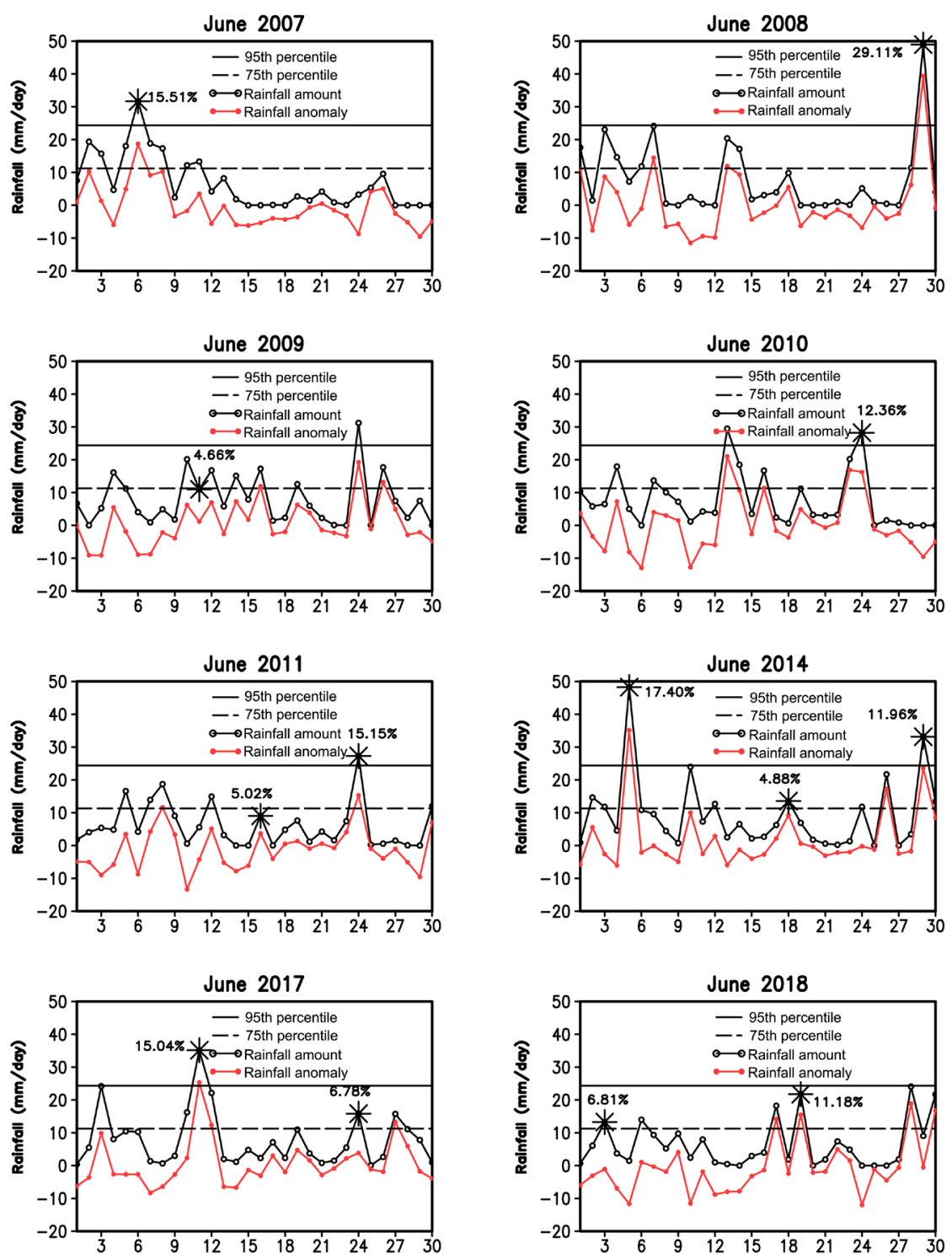

Figure 2. Daily time series of GPCP (black curve, $\mathrm{mm}$ /day) and the corresponding anomalies (red curve, $\mathrm{mm} /$ day) at a grid point $\left(4.5^{\circ} \mathrm{W} ; 5.5^{\circ} \mathrm{N}\right)$ close to Abidjan in 2007,2008 , 2009, 2010, 2011, 2014, 2017 and 2018 corresponding to the years during which submersion flood events were observed. The horizontal dashed lines at $11.27 \mathrm{~mm} /$ day (solid black line) and $24.36 \mathrm{~mm} /$ day (dashed black line) represent the 95 th and the 75 th percentile thresholds used to identify the submersion flood events. The thirteen selected events are marked by stars. The numbers in each figure represent the percentage of the submersion flooding event during the corresponding year.

as the difference between $1000 \mathrm{hPa}$ and the daily level reached by the flux. The maximum depth reaches around $700 \mathrm{hPa}(\sim 300 \mathrm{hPa}$ level), while the minimum depth is about $160 \mathrm{hPa}(\sim 840 \mathrm{hPa}$ level). The daily climatology of depth also shows that the monsoon flow is below the $500 \mathrm{hPa}(\sim 500 \mathrm{hPa}$ level) most of the month, especially during the June, 11-25 period. This last period corresponds to the maximum number of events ( 10 events) listed by SODEXAM (see Figure 2). The monsoon flow that reaches Abidjan in June is located about $700 \mathrm{hPa}$ 


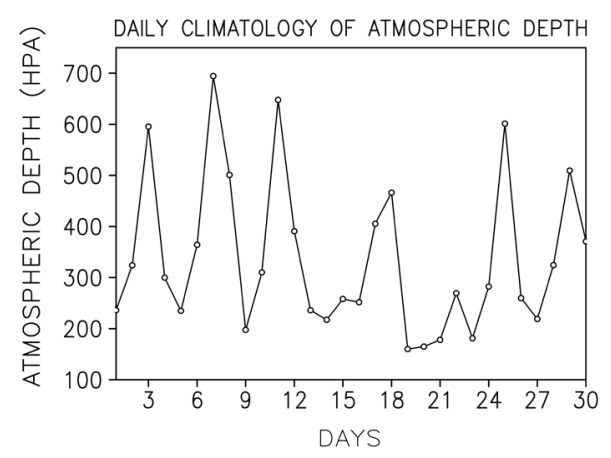

Figure 3. Mean atmospheric depth of the monsoon calculated as the difference between $1000 \mathrm{hPa}$ and the daily level reached by the flow. The discontinuous line at $300 \mathrm{hPa}$ represents approximately the $700 \mathrm{hPa}$ atmospheric level.

( $\sim 300 \mathrm{hPa}$ depth) on average, that correspond to a low-level atmospheric flow. This observation is in agreement with Burpee [24] and Zhang et al. [25] who showed that the monsoon flow from Atlantic Ocean, which influences Côte d'Ivoire, was particularly concentrated in the lower atmospheric layers between $1000 \mathrm{hPa}$ and $500 \mathrm{hPa}$ levels. The mean atmospheric level $(\sim 700 \mathrm{hPa})$ corresponds to that generally used for the study of the easterly waves [32] [33].

Figure 4 illustrates the evolution of the mean atmospheric depth of the monsoon flow during the day when the 13 selected events are observed. The $300 \mathrm{hPa}$ depth corresponding to the $700 \mathrm{hPa}$ atmospheric level is shown. The events above the 95th (respectively 75th) percentile threshold are marked by a close circle (respectively circle). High values of monsoon depth are observed in 2009, 2014, 2017 and 2018. Such a depth increase along the coast of West Africa could lead to greater penetration of monsoon flow over this region and thus influence the intensity of extreme rainfall amounts [8]. The highest depths $(\sim 700 \mathrm{hPa}$, i.e. $300 \mathrm{hPa}$ level) are observed during the rainfall events of June 11, 2009, June 11, 2017 and June 03, 2018. Eight events are observed when the monsoon flow is located at the low levels between 0 and $500 \mathrm{hPa}$ atmospheric depth. As noted, these events have practically the highest rainfall contributions, and present the maximum number of extreme events ( 6 events). The remaining five events take place for monsoon flow in the upper layers above $500 \mathrm{hPa}(\sim 500 \mathrm{hPa}$ level). Such discrimination in the influence of monsoon depth could allow studying the influence of the integrated moisture flux by taking into account the atmospheric layer associated with each event.

\subsection{Relationship with Easterly Waves Propagation}

In this section, the relationship between easterly waves and these rain flooding events that caused material and human damages is analyzed. This study is carried out because eight of the 13 events ( $62 \%)$ occur when the moisture flow is located at the lower layers of the atmosphere. Figure 5 presents the meridian wind at $700 \mathrm{hPa}$, averaged between $5^{\circ} \mathrm{N}$ and $15^{\circ} \mathrm{N}$ along $10^{\circ} \mathrm{W}-20^{\circ} \mathrm{E}$ for each month of June during the 2007-2018 period. Only the positive values are shaded 


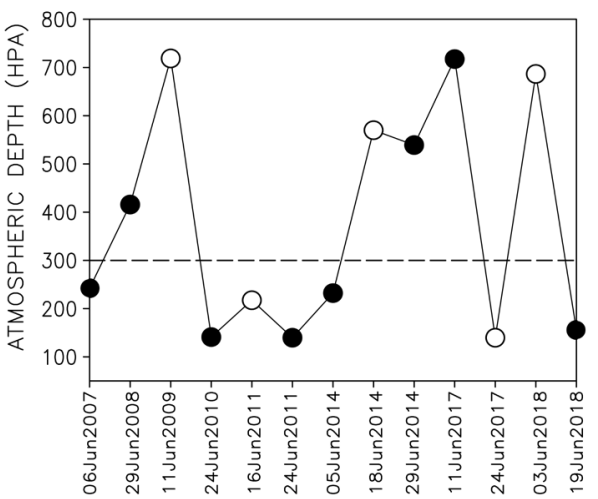

Figure 4. Atmospheric depth of the monsoon for each of the thirteen events. Events with rainfall great than the $95^{\text {th }}$ (resp. less than the $75^{\text {th }}$ ) percentile threshold are marked by closed circle (resp. open circle). The discontinuous line at $300 \mathrm{hPa}$ represents approximately the $700 \mathrm{hPa}$ atmospheric level.
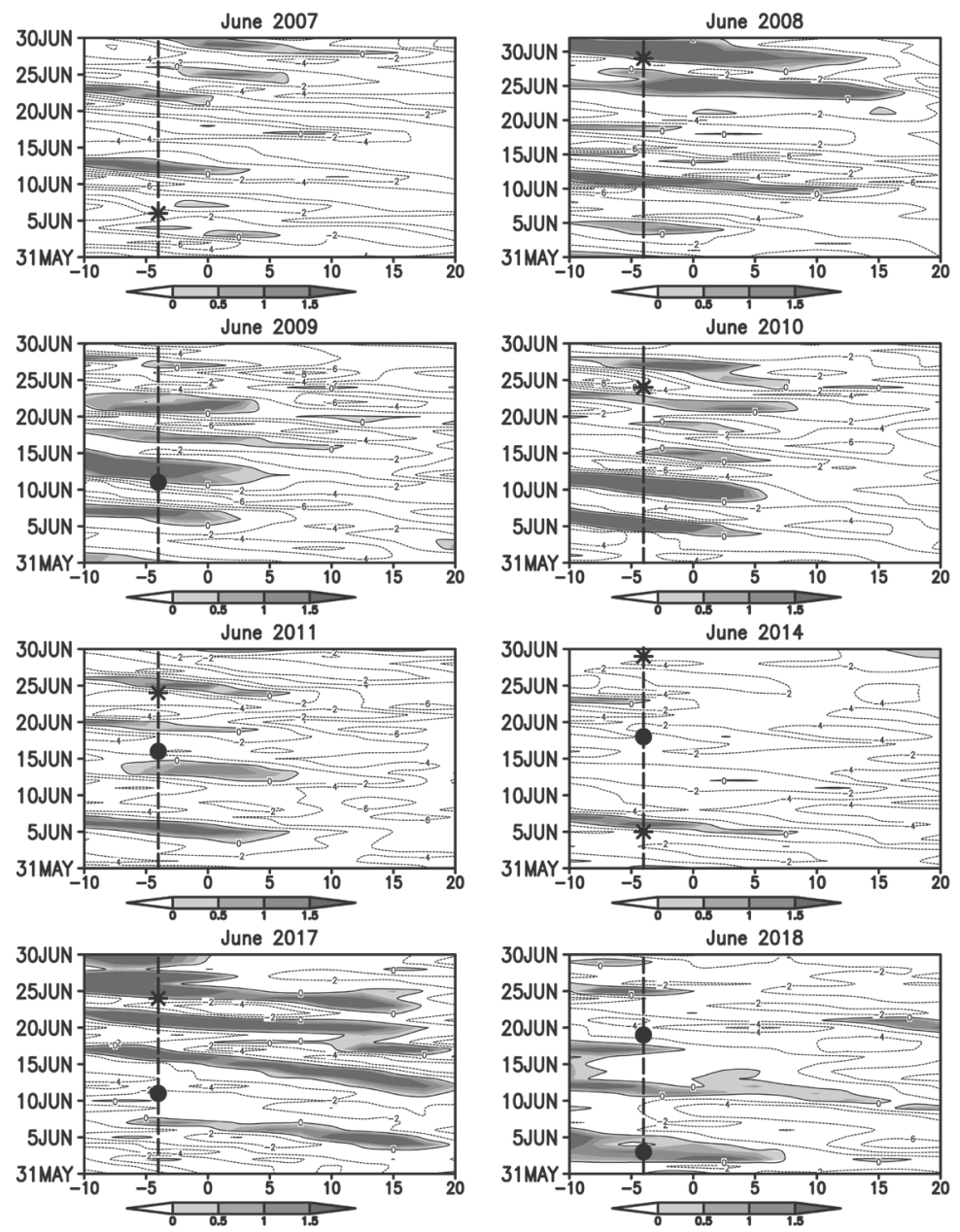

Figure $5.700 \mathrm{hPa}$ daily vertical wind along $10^{\circ} \mathrm{W}-20^{\circ} \mathrm{E}$ averaged between $5^{\circ} \mathrm{N}$ and $15^{\circ} \mathrm{N}$ of June in 2007, 2008, 2009, 2010, 2011, 2014, 2017 and 2018 corresponding to the years during which submersion flood events were observed. The vertical dashed line at $\sim 4^{\circ} \mathrm{W}$ represents the approximate longitude of Abidjan (Côte d'Ivoire). Observed rain flooding events $>95^{\text {th }}$ and $>75^{\text {th }}$ percentile are schematized by stars and black dots respectively at $4^{\circ} \mathrm{W}$. 
to illustrate the propagation of easterly waves. The 13 events are represented by stars (respectively black dots) for those above the 95th (respectively 75th) percentile along the meridian line at $5.3^{\circ} \mathrm{W}$ corresponding to the longitude of $\mathrm{Ab}$ idjan.

Four events (June 29, 2008; June 11, 2009; June 25, 2017; June 3, 2018), which represent around the third of all events, are associated with easterly wave propagation (Table 2). That means a proportion of two events (June 29, 2008 and June 25,2017 ) above the 95th percentile and two events (June 11, 2009 and June 3,2018 ) above the 75 th percentile. These events have a phase velocity between $7.19 \mathrm{~m} / \mathrm{s}$ and $10.19 \mathrm{~m} / \mathrm{s}$ (an average of $\sim 8.46 \mathrm{~m} / \mathrm{s}$ ) and a period of 1 to 4 days (an average of $\sim 2.5$ days). Indeed, those events above the 95th percentile are generated by the easterly waves propagating from Eastern Africa towards $20^{\circ} \mathrm{E}$, close to the Joss Plate [8]. This area is known as an initiation zone for convective systems crossing West Africa. Likewise, events above the 75th percentile are associated with easterly waves initiated around $5^{\circ} \mathrm{E}$, i.e. closer to Abidjan. As previously observed, extreme events exhibit contribution greater than $10 \%$, while that of intense events do not exceed $7 \%$. Let us also note that easterly waves are more active in August-September than in June-July [33]. That is in agreement with the lower number of rain flooding events in June related to these atmospheric disturbances. The remaining events could be influenced by other atmospheric processes, as for instance cold fronts from the southern tropical Atlantic and the Madden-Julian oscillation, not considered in this study. It would be interesting to extend, in future works, this study to all events, whether or not they create flooding, to clearly identify the processes involved in their occurrence.

\subsection{Ocean and Atmospheric Conditions Associated with Rain Flooding Events}

The impact of oceanic and atmospheric conditions on the rain flooding events that occurred in Abidjan is analyzed. This impact is studied by plotting the June SST daily anomalies for the 2007-2018 period, the daily specific humidity, the vertical wind, the meridian gradient of absolute vorticity at $700 \mathrm{hPa}$ and the vertically integrated moisture flux on the $1000-700 \mathrm{hPa}$ and $700-300 \mathrm{hPa}$ columns.

Table 2. Characteristics of the four events associated to easterly wave (EW). The day of strong rainfall episode over Abidjan, lifespan of EW (days), and EW virtual velocity $\left(\mathrm{m} \cdot \mathrm{s}^{-1}\right)$ are given for each event.

\begin{tabular}{ccccc}
\hline $\begin{array}{c}\text { Day of } \\
\text { the event }\end{array}$ & $\begin{array}{c}\text { Contribution of the event } \\
\text { to the monthly rainfall (\%) }\end{array}$ & Threshold & $\begin{array}{c}\text { Lifespan of } \\
\text { EW (days) }\end{array}$ & $\begin{array}{c}\text { EW virtual } \\
\text { velocity }\left(\mathrm{m} \cdot \mathrm{s}^{-1}\right)\end{array}$ \\
\hline June 29, 2008 & 29.11 & 95 & 3 & 7.21 \\
June 11, 2009 & 4.66 & 75 & 1 & 10.19 \\
June 25, 2017 & 15.04 & 95 & 4 & 9.25 \\
June 3, 2018 & 6.81 & 75 & 2 & 7.19 \\
& & Average & 2.5 & 8.46 \\
\hline
\end{tabular}


The monthly composite pattern of SST anomalies performed for June from 2007 to 2018 shows a well-marked dipole between the cold northern and warm southern basins of the tropical Atlantic (not shown). The boundary line between these two basins lies at the thermal equator $\left(\sim 5^{\circ} \mathrm{N}\right)$ which corresponds to the position of the Intertropical Convergence Zone (ITCZ) at this time of year. This position of the ITCZ allows the transportation of moisture flux from the ocean to the coast of the Gulf of Guinea and contributes to the enhancement of rainfall.

To study the particularities that could exist for each event, daily anomaly patterns for four days before extreme or the intense rainfall event (Figure 6(a)) and for the onset day of this given event (Figure 6(b)) are produced. This time lag highlights the persistence of the thermal structures observed in both figures. The ocean warming observed four days before the onset day in Figure 6(a) enhances during the onset day in Figure 6(b). Such Ocean warming could influence the occurrence of the rain-fall event. The figures present three different structures of SST anomalies. The first structure concerns the warming of the equatorial rail and the Atlantic cold tongue during the events of 2007 and 2018. The observed SST anomalies above $1.5^{\circ} \mathrm{C}$ during the rainfall events of June 06, 2007 and June 19, 2018 are a similar structure like the Pacific El-Niño well described in previous works [2] [34]. This abnormal warming could lead to strong oceanic evaporation causing increased instability of the lower monsoon layers over the sea and the coastline, and to higher humidity gradient creating a maximum mass advection. This is consistent with Caniaux et al. [35] who noticed that the Atlantic cold tongue plays a key role in West African monsoon variability.

The second structure illustrates a global warming of the whole ocean basin during the events of June 11 and June 24, 2017, June 29, 2008 and June 24, 2010.

Finally, the third structure indicates a north-south dipole of SST anomalies. This dipole shows a warming (respectively cooling) in the southern (respectively northern) basin in 2014 and 2009 and an inversion in 2011. This structure is consistent with the monthly composite structure of the anomalies seen in the previous paragraph (not shown). Likewise, the observed north-south dipole of SST anomalies corresponds to the second mode of interannual variability in the tropical Atlantic Ocean [36]. It results in a North-South oscillation whose axis of division lies at the ITCZ level. These different results provide the occurrence of these events is associated with particular patterns of tropical Atlantic SST anomalies. Other oceanic parameters, not considered here, could also influence these extreme events, as for instance the wind stress, the heat content and the ocean heat flux. It would be interesting to go further in future oceanic variables analysis to better understand the processes involved in their occurrence.

The evolution of upward motion in the atmosphere is also analyzed (Figure 7). The altitude-latitude composite diagram of the vertical velocity averaged over $10^{\circ} \mathrm{W}-10^{\circ} \mathrm{E}$ (Figure 7 , left) and its corresponding anomaly pattern (Figure 7, right) during the onset of events. Negative values indicate an upward motion of air masses, which allows inputting moisture into the troposphere, while positive values are associated with air subsidence. The upward motion of air flow extends 

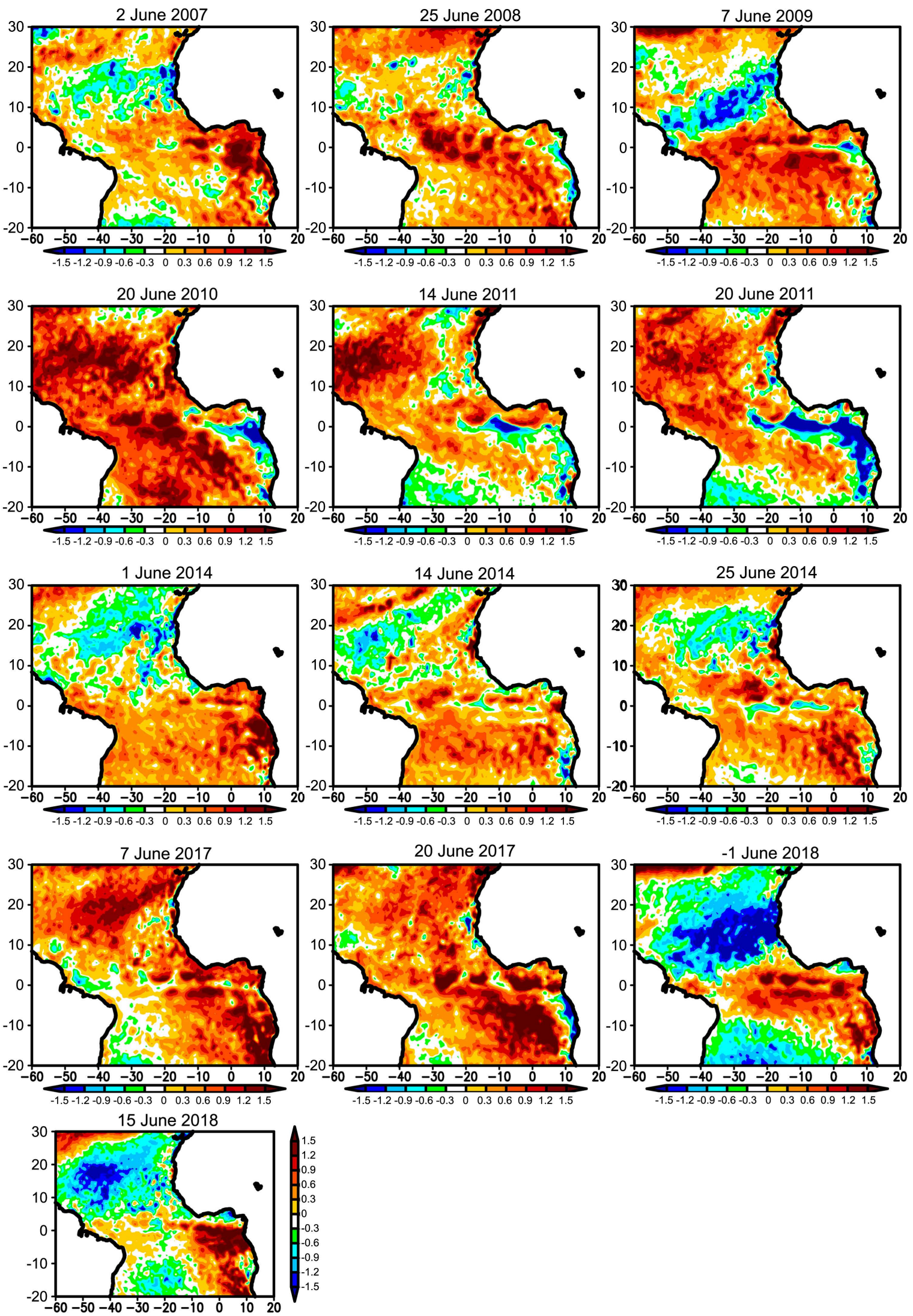

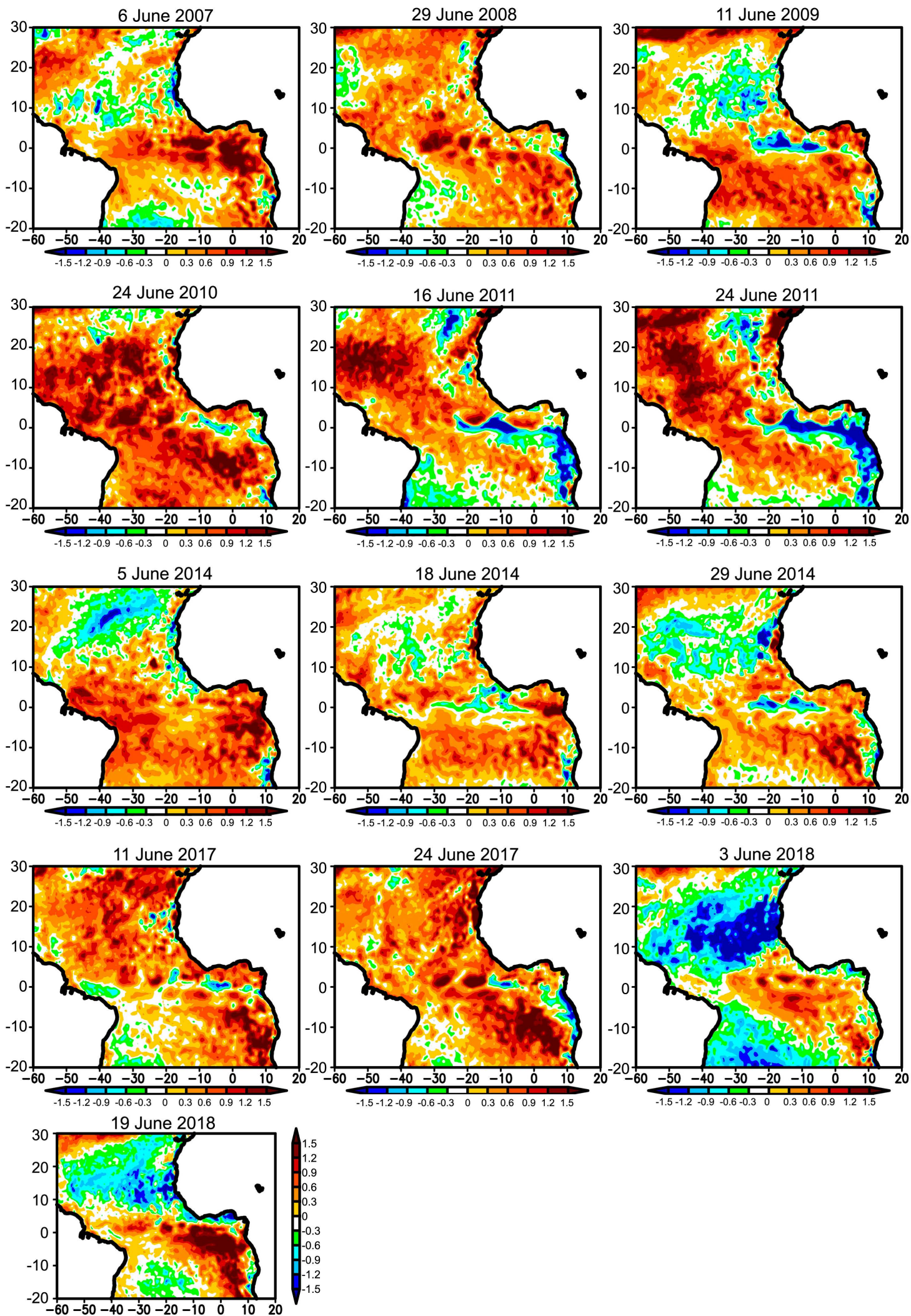

(b)

Figure 6. (a) Latitude-longitude daily anomalies of SST $\left({ }^{\circ} \mathrm{C}\right)$ four days before the onset day of each event; (b) Latitude-longitude daily anomalies of SST $\left({ }^{\circ} \mathrm{C}\right)$ of the onset day of each event. 

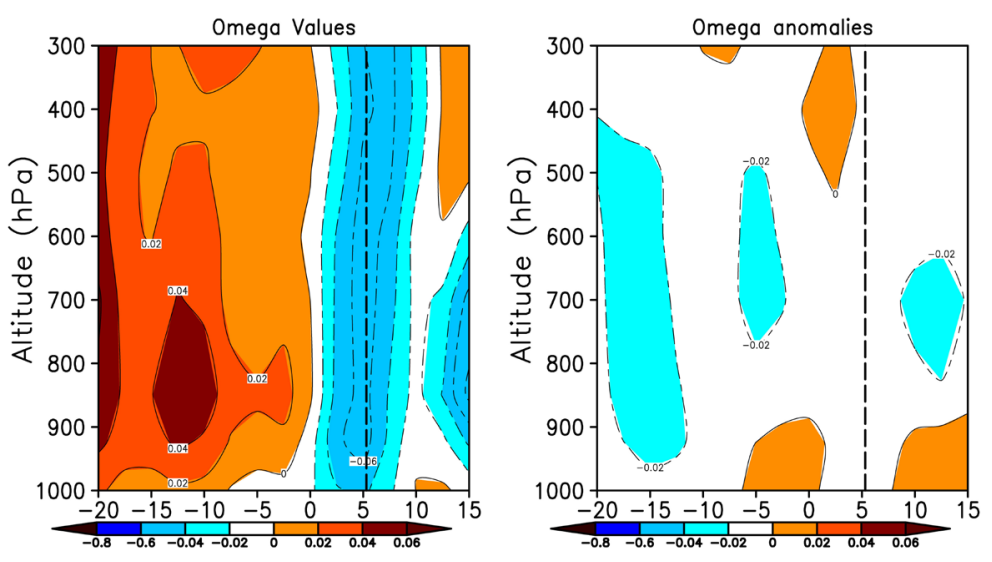

Figure 7. Composite diagram of altitude-latitude values (left) and anomalies (right) of the vertical velocity $\left(10^{-3} \mathrm{hPa} \cdot \mathrm{s}^{-1}\right)$ averaged over $10^{\circ} \mathrm{W}-10^{\circ} \mathrm{E}$ during the periods of the selected events during 2007-2018. Upward motion (negative values) is shaded. The vertical dashed line at $\sim 5.309^{\circ} \mathrm{N}$ represents the approximate latitude of the coastline at Abidjan (Côte d'Ivoire).

from the ocean toward the equator to the continent beyond $10^{\circ} \mathrm{N}$. However, the high values $\left(\sim-0.02 \mathrm{~m} / \mathrm{s}\right.$ ) are located in the latitudinal band between $3^{\circ} \mathrm{N}$ (on the ocean) and $7^{\circ} \mathrm{N}$ (on the continent) including the coastline. Particularly, the highest values $(\sim-0.06 \mathrm{~m} / \mathrm{s})$ are located practically at the coast from $950 \mathrm{hPa}$ to $500 \mathrm{hPa}$. This value is due to a combined action of oceanic and continental influences in the occurrence of these rain flooding events. It also confirms the importance of the latitudinal band $0^{\circ} \mathrm{N}-10^{\circ} \mathrm{N}$ in bringing excess moisture from the surface to the upper layers of the atmosphere, which could contribute to enhancing rainfall during these periods. Li et al. [37] and Ta et al. [8] explained this phenomenon by greater convergence of oceanic and continental excess moisture input into the lower troposphere, which could influence monsoon circulation and affect rainfall.

Figure 8 displays the composite pattern of the meridian gradient of absolute vorticity at $700 \mathrm{hPa}$, and the vertically integrated moisture flux and specific humidity anomalies performed in the $1000 \mathrm{hPa}-700 \mathrm{hPa}$ and $700 \mathrm{hPa}-300 \mathrm{hPa}$ columns.

Negative values of the meridian gradient are located around $10^{\circ} \mathrm{N}$ over West Africa. These negative values lie between the positive values at the north of the Gulf of Guinea at around $0^{\circ} \mathrm{N}-5^{\circ} \mathrm{N}$, and on the continent at around $20^{\circ} \mathrm{N}$. It should also be noted that the ITCZ and its ground track, which is the intertropical front (FIT) on the continent, is located at this period around $5^{\circ} \mathrm{N}$, i.e. between the first positive vorticity structure in the south around $5^{\circ} \mathrm{N}$ and the negative vorticity structure. This observation is corroborated by the results of Ferreira and Schubert mentioning that convection at the ITCZ creates such an inversion of the signs [38]. This implies an increase in disturbance indicating that these events follow, at this level, the Charney-Stern [29] criterion of barotropic instability. On the other hand, this instability could contribute to the intensification of these rain flooding events in Abidjan. In addition, this zone of instability 


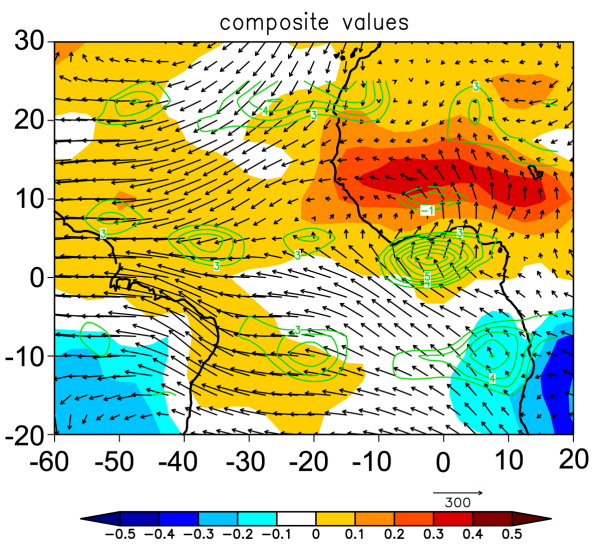

(a)

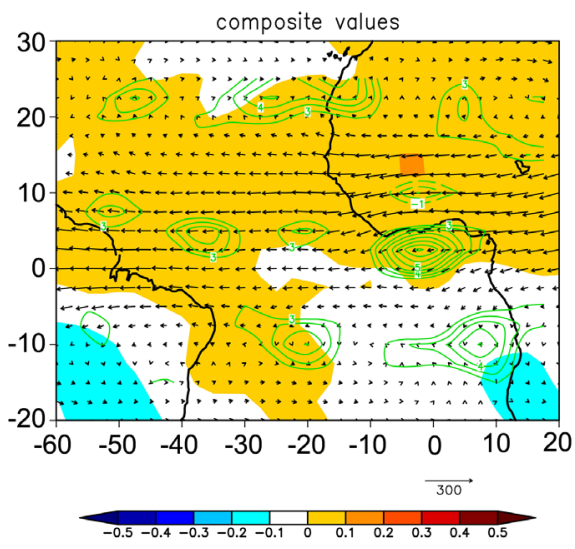

(b)

Figure 8. Latitude-longitude composite daily values of integrated moisture flux $\left(\times 10^{-4}\right.$ $\mathrm{g} / \mathrm{kg} / \mathrm{s}$, vectors) and anomalies of specific humidity calculated from $1000 \mathrm{hPa}$ to $700 \mathrm{hPa}$ (top) and $700 \mathrm{hPa}$ to $300 \mathrm{hPa}$ (bottom). Absolute vorticity at $700 \mathrm{hPa}\left(\times 10^{-11} \mathrm{~s} / \mathrm{m}\right.$, contours) is also plotted.

forms in the moisture streamlines due to the monsoon surge [39], which is a characteristic of the types of disturbed weather.

The composite of specific humidity anomalies has positive values between the equator and $20^{\circ} \mathrm{N}$ with the highest values $(>0.3 \mathrm{~g} / \mathrm{kg})$ located around $10^{\circ} \mathrm{N}$ over West Africa between $1000 \mathrm{hPa}$ and $700 \mathrm{hPa}$. These lower positive values do not exceed $0.1 \mathrm{~g} / \mathrm{kg}$ between $700 \mathrm{hPa}$ and $300 \mathrm{hPa}$ showing the flow which influences most of these events is located mainly in the lower atmospheric layers. Moreover, the oceanic part of the Gulf of Guinea between the equator and the coastline contributes to the intensification of these events by introducing moisture into the atmosphere. This observation on excess moisture location is consistent with the vertical velocity observed during these events.

Finally, the vertically integrated moisture flux between $1000 \mathrm{hPa}$ and $700 \mathrm{hPa}$ confirms the inflow to the continent of oceanic moisture from the ventilation by evaporation of warm water into the atmosphere. The direction of this horizontal moisture gradient could explain the increase in rainfall along the coast in June. This parameter also provides, between $700 \mathrm{hPa}$ and $300 \mathrm{hPa}$, a strong moisture 
flux from Eastern Africa towards $20^{\circ} \mathrm{E}$, which includes the Joss Plate [8]. This eastern zone of Africa is known as an initiation zone for convective systems crossing West Africa. The vertically integrated moisture flux structure could also correspond to the intensification of the African easterly jet during these events [32]. These two observations thus result in a combined action of the influence of both oceanic and continental zones in the occurrence of the events.

\section{Conclusions}

This study analyses rain flooding events in June on the coastal area of West Africa, particularly in Abidjan, which is the economic capital of Côte d'Ivoire. The June period corresponds to the core of the great rainy season over West Africa coast during which most of the dramatic rainfall events occur. This work also relates these events to oceanic and atmospheric conditions that could influence them. The variability of the rainfall events is studied by using the 95th and 75th percentiles, which represent extreme and intense rainfall events respectively.

The trend of the cumulative intense rainfall amount decreases, while that of extreme rainfall amount increases. The sum of their contributions reaches almost $50 \%$ and shows the importance of these two events in the June rainfall. Particularly, the two extreme events per year are likely to produce about $\sim 1 / 5$ of the June rainfall.

The West African monsoon that reaches Abidjan in June during these events corresponds to a low-level atmospheric flow. The atmospheric depth increasing for certain years along the coast of West Africa could lead to greater penetration of monsoon flow over this region, and thus influence the intensity of extreme rainfall amounts. A proportion of $31 \%$ (third) of events is associated with easterly wave propagation.

The impact of oceanic and atmospheric conditions on the rain flooding events is also analyzed by using different sets of data. Daily SST anomalies provide three different structures. The first one concerns the warming of the equatorial rail and the Atlantic cold tongue during these events. The second pattern is related to a warming of the whole ocean basin. Finally, the third structure indicates a north-south dipole of SST anomalies.

The upward motion in the atmosphere shows air flow that extends in latitude from the ocean toward the equator to the continent beyond $10^{\circ} \mathrm{N}$. Negative values of the meridian gradient of absolute vorticity lie between the positive values at the north of the Gulf of Guinea at around $0^{\circ} \mathrm{N}-5^{\circ} \mathrm{N}$, and in the continent at around $20^{\circ} \mathrm{N}$. The composite pattern of specific humidity anomalies shows positive values between the equator over the ocean and $20^{\circ} \mathrm{N}$ on the continent. These values are highest in the $1000 \mathrm{hPa}-700 \mathrm{hPa}$ column. Finally, the vertically integrated moisture flux between $1000 \mathrm{hPa}$ and $700 \mathrm{hPa}$ confirms the inflow to the continent of oceanic moisture from the ventilation by evaporation of warm water into the atmosphere. 
In this study, ocean-atmosphere processes that can be monitored in real-time have the potential to improve the forecasting of strong precipitation episodes during the seasonal rainfall over West Africa coastal area. Coupled model simulations could then give one useful dynamical basis for such ocean-atmosphere processes. Such initiatives are encouraged to better explain these dramatic rainfall phenomena. That is one of the objectives of the "Jeune Equipe Associée à l'IRD” named "Interactions et Variabilité Océan Atmosphère Régionales liées à l'Upwelling (JEAI IVOARE-UP)".

Further analyses are also in progress to understand the atmospheric processes which contribute to the occurrence of some events not relating to easterly waves. Such a study is important to propose solutions that could allow the adoption of adequate policies for the management of risks related to these events, and particularly to civil protection and urban planning.

\section{Acknowledgements}

The authors thank the "Laboratoire mixte international Climat-Eau-EnergieAgriculture en Afrique de POuest et Services Climatiques (Lmi Nexus)" and the "Jeune Equipe associé à PIRD-IVOARE-UP" for their financial support. They are grateful to Dr. U. Koffi who helped in improving the English form of the paper.

\section{Conflicts of Interest}

The authors declare no conflicts of interest regarding the publication of this paper.

\section{References}

[1] Ochou, A.D., Aman, A., Kouadio, K.Y. and Assamoi, P. (2005) Nouveau zonage climatique basé sur la variabilité pluviométrique en Côte d'Ivoire et au Ghana. Geotrope, 5, 34-46.

[2] Kouadio, Y.K., Ochou, D.A. and Servain, J. (2003) Tropical Atlantic and Rainfall Variability in Côte d'Ivoire. Geophysical Research Letters, 30, 8005.

https://doi.org/10.1029/2002GL015290

[3] Kouadio, Y.K., Ali, K.E., Zahiri, E.-P. and Assamoi, A.P. (2007) Etude de la prédictibilité de la pluviométrie en Côte d'Ivoire durant la période de Juillet à Septembre. Revue Ivoirienne des Sciences et Technologie, 10, 117-134.

[4] ONU-Habitat (2006) Côte d'Ivoire: Profil urbain de la ville d'Abidjan, édité par le Programme des Nations unies pour les établissement humains. UNON, Nairobi, $1-46$.

[5] Reason, C.J.C. and Rouault, M. (2006) Sea Surface Temperature Variability in the Tropical Southeast Atlantic Ocean and West African Rainfall. Geophysical Research Letters, 33, L21705. https://doi.org/10.1029/2006GL027145

[6] Lutz, K., Jacobeit, J. and Rathmann, J. (2015) Atlantic Warm and Cold Water Events and Impact on African West Coast Precipitation. International Journal of Climatology, 35, 128-141. https://doi.org/10.1002/joc.3969

[7] Ali, K.E., Kouadio, K.Y., Zahiri, E.-P., Aman, A., Assamoi, A.P. and Bourles, B. 
(2011) Influence of the Gulf of Guinea Coastal and Equatorial Upwellings on the Precipitations along Its Northern Coasts during the Boreal Summer Period. Asian Journal of Applied Science, 4, 271-285. https://doi.org/10.3923/ajaps.2011.271.285

[8] Ta, S., Kouadio, K.Y., Ali, K.E., Toualy, E., Aman, A. and Yoroba, F. (2016) West Africa Extreme Rainfall Events and Large-Scale Ocean Surface and Atmospheric Conditions in the Tropical Atlantic. Advances in Meteorology, 2016, Article ID: 1940456. https://doi.org/10.1155/2016/1940456

[9] Lafore, J.-P., Beucher, F., Peyrille, P., Diongue-Niang, A., Chapelon, N., Bouniol, D., Caniaux, G., Favot, F., Ferry, F., Guichard, F., Poan, E., Roehrig, R. and Vischel, Th. (2017) A Multi-Scale Analysis of the Extreme Rain Event of Ouagadougou in 2009. Quarternary Journal of the Royal Meteorololgical Society, 143, 3094-3109.

https://doi.org/10.1002/qj.3165

[10] Panthou, G., Vischel, T., Lebel, T., Blanchet, J., Quantin, G. and Ali, A. (2012) Extreme Rainfall in West Africa: A Regional Modeling. Water Resources Research, 48, W08501. https://doi.org/10.1029/2012WR012052

[11] Ibrahim, B., Polcher, J., Karambiri, H. and Rockel, B. (2012) Characterization of the Rainy Season in Burkina Faso and It's Representation by Regional Climate Models. Climate Dynamics, 39, 1287-1302. https://doi.org/10.1007/s00382-011-1276-X

[12] Goula, B.T., Soro, E.G., Kouassi, W. and Srohourou, B. (2012) Tendances et ruptures au niveau des pluies journalieres extrêmes en Côte d'Ivoire (Afrique de l'Ouest). Hydrological Science Journal, 57, 1067-1080. https://doi.org/10.1080/02626667.2012.692880

[13] Huffman, G.J., Adler, R.F., Morrissey, M.M., Bolvin, D.T., Curtis, S., Joyce, R., McGavock, B. and Susskind, J. (2001) Global Precipitation at One-Degree Daily Resolution from Multisatellite Observations. Journal of Hydrometeorology, 2, 36-50. https://doi.org/10.1175/1525-7541(2001)002<0036:GPAODD >2.0.CO;2

[14] Jobard, I., Chopin, F., Berges, J.C. and Roca, R. (2009) An Intercomparison of 10-Day Satellite Precipitation Products during West African Monsoon. International Journal of Remote Sensing, 32, 2353-2376. https://doi.org/10.1080/01431161003698286

[15] Roca, R., CHambon, P., Jobard, I., Kirstetter, P.E., Gosset, M. and Berges, J.C. (2010) Comparing Satellite and Surface Rainfall Products over West Africa at Meteorologically Relevant Scales during the AMMA Campaign Using Errors Estimates. Journal of Applied Meteorology and Climatology, 49, 715-731.

https://doi.org/10.1175/2009JAMC2318.1

[16] Reynolds, R.W., Rayner, N.A., Smith, T.M., Stokes, D.C. and Wang, W. (2002) An Improved in Situ and Satellite SST Analysis for Climate. Journal of Climate, 15, 1609-1625. https://doi.org/10.1175/1520-0442(2002)015<1609:AIISAS>2.0.CO;2

[17] Kalnay, E., Kanamitsu, M., Kistler, R., Collins, W., Deaven, D., Gandin, L., Iredell, M., Saha, S., White, G., Woollen, J., Zhu, Y., Chelliah, M., Ebisuzaki, W., Higgins, W., Janowiak, J., Mo, K.C., Ropelewski, C., Wang, J., Leetmaa, A., Reynolds, R., Jenne, R. and Joseph, D. (1996) The NCEP/NCAR 40-Year Reanalysis Project. Bulletin of the American Meteorological Society, 77, 437-472. https://doi.org/10.1175/1520-0477(1996)077<0437:TNYRP>2.0.CO;2

[18] Huang, W., Chang, S.-Q., Xie, C.-L. and Zhang, Z.-P. (2017) Moisture Sources of Extreme Summer Precipitation Events in North Xinjiang and Their Relationship with Atmospheric Circulation. Advances in Climate Change Research, 8, 12-17. https://doi.org/10.1016/j.accre.2017.02.001

[19] Zhang, X., Alexander, L., Hegerl, G.C., Jones, P., Tank, A.K., Peterson, T.C., Trewin, 
B. and Zwiers, F.W. (2011) Indices for Monitoring Changes in Extremes Based on Daily Temperature and Precipitation Data. WIREs Climate Change, 2, 851-870. https://doi.org/10.1002/wcc.147

[20] Alexander, L.V., Zhang, X., Peterson, T.C., Caesar, J., Gleason, B., Klein Tank, A.M.G., Haylock, M., Collins, D., Trewin, B., Rahimzadeh, F., Tagipour, A., Rupa Kumar, K., Revadekar, J., Griffiths, G., Vincent, L., Stephenson, D.B., Burn, J., Aguilar, E., Brunet, M., Taylor, M., New, M., Zhai, P., Rusticucci, M. and Vazquez-Aguirre, J.L. (2006) Global Observed Changes in Daily Climate Extremes of Temperature and Precipitation. Journal of Geophysical Research Atmosphere, 111, D05109. https://doi.org/10.1029/2005JD006290

[21] Ma, S. and Zhou, T. (2015) Observed Trends in the Timing of Wet and Dry Season in China and the Associated Changes in Frequency and Duration of Daily Precipitation. International Journal of Climatology, 35, 4631-4641.

https://doi.org/10.1002/joc.4312

[22] Gao, T., Wang, H.J. and Zhou, T. (2017) Changes of Extreme Precipitation and Nonlinear Influence of Climate Variables over Monsoon Region in China. Atmospheric Research, 197, 379-389.

https://doi.org/10.1016/j.atmosres.2017.07.017

[23] Cao, F., Gao, T., Dan, L., Ma, Z., Yang, X. and Yang, F. (2018) Contribution of Large-Scale Circulation Anomalies to Variability of Summer Precipitation Extremes in Northeast China. Atmospheric Science Letters, 19, e867. https://doi.org/10.1002/asl.867

[24] Burpee, R.W. (1972) The Origin and Structure of Easterly Waves in the Lower Troposphere of North Africa. Journal of Atmospheric Science, 29, 77-90. https://doi.org/10.1175/1520-0469(1972)029<0077:TOASOE $>2.0 . C O ; 2$

[25] Zhang, C., Woodworth, P. and GU, G. (2006) The Seasonal Cycle in the Lower Troposphere over West Africa from Sounding Observations. Quaterly Journal of the Royal Meteorological Society, 132, 2559-2582. https://doi.org/10.1256/qj.06.23

[26] Diawara, A., Yoroba, F., Kouadio, K.Y., Kouassi, K.B., Assamoi, E.M., Diedhiou, A. and Assamoi, P. (2014) Climate Variability in the Sudano-Guinean Transition Area and Its Impact on Vegetation: The Case of the Lamto Region in Côte d'Ivoire. $A d$ vances in Meteorolology, 2014, Article ID: 831414.

https://doi.org/10.1155/2014/831414

[27] Molinari, J., Knight, D., Dickinson, M., Vollaro, D. and Skubis, S. (1997) Potential Vorticity, Easterly Waves, and Tropical Cyclogenesis. Monthly Weather Review, $125,2699-2708$. https://doi.org/10.1175/1520-0493(1997)125<2699:PVEWAE>2.0.CO;2

[28] Molinari, J., Vollaro, D., Skubis, S. and Dickinson, M. (2000) Origins and Mechanisms of Eastern Pacific Tropical Cyclogenesis: A Case Study. Monthly Weather Review, 128, 125-139. https://doi.org/10.1175/1520-0493(2000)128<0125:OAMOEP >2.0.CO;2

[29] Hsieh, J.-S. and Cook, K.H. (2008) On the Instability of the African Easterly Jet and the Generation of African Waves: Reversals of the Potential Vorticity Gradient. Journal of the Atmospheric Science, 65, 2130-2151. https://doi.org/10.1175/2007JAS2552.1

[30] Liebmann, B., Kiladis, G.N., Allured, D., Vera, C.S., Jones, C., Carvalho, M.V., Bladé, I. and Gonzales, P.L.M. (2011) Mechanisms Associated with Large Daily Rainfall Events in Northeast Brazil. Journal of Climate, 24, 376-396. https://doi.org/10.1175/2010JCLI3457.1 
[31] Kouadio, K.Y., Servain, J., Machado, L.A.T. and Lentini, C.A.D. (2012) Heavy Rainfall Episodes in the Eastern Northeast Brazil Linked to Large-Scale Ocean-Atmosphere Conditions in the Tropical Atlantic. Advances in Meteorology, 2012, Article ID: 369567. https://doi.org/10.1155/2012/369567

[32] Diedhiou, A., Janicot, S., Viltard, A. and De Felice, P. (1998) Evidence of Two Regimes of Easterly Waves over West Africa and the Tropical Atlantic. Geophysical Research Letters, 25, 2805-2808. https://doi.org/10.1029/98GL02152

[33] Diedhiou, A., Janicot, S., Viltard, A., De Felice, P. and Laurent, H. (1999) Easterly Wave Regimes and Associated Convection over West Africa and Tropical Atlantic: Results from the NCEP/NCAR and ECMWF Reanalyses. Climate Dynamics, 15, 795-822. https://doi.org/10.1007/s003820050316

[34] Ding, H., Keenlyside, N.S. and Latif, M. (2012) Impact of the Equatorial Atlantic on the El Niño Southern Oscillation. Climate Dynamics, 38, 1965-1972. https://doi.org/10.1007/s00382-011-1097-y

[35] Caniaux, G., Giordani, H., Redelsperger, J.-L., Guichard, F., Key, E. and Wade, M. (2011) Coupling between the Atlantic Cold Tongue and the West African Monsoon in Boreal Spring and Summer. Journal of Geophysical Research, 116, C04003. https://doi.org/10.1029/2010JC006570

[36] Torralba, V., Rodríguez-Fonseca, B., Mohino, E. and Losada, T. (2015) The Non-Stationary Influence of the Atlantic and Pacific Niños on North Eastern South American Rainfall. Frontiers in Earth Science, 3, 55. https://doi.org/10.3389/feart.2015.00055

[37] Li, H.L., Wang, H.J. and Yin, Y.Z. (2012) Interdecadal Variation of the West African Summer Monsoon during 1979-2010 and Associated Variability. Climate Dynamics, 39, 2883-2894. https://doi.org/10.1007/s00382-012-1426-9

[38] Ferreira, R.N. and Schubert, W.H. (1997) Barotropic Aspects of ITCZ Breakdown. Journal of Atmospheric Science, 54, 261-285. https://doi.org/10.1175/1520-0469(1997)054<0261:BAOIB >2.0.CO;2

[39] Couvreux, F., Guichard, F., Bock, O., Campistron, B., Lafore, J.-P. and Redelsperger, J.-L. (2010) Synoptic Variability of the Monsoon Flux over West Africa Prior to the Onset. Quaterly Journal of the Royal Meteorological Society, 136, 159-170.

https://doi.org/10.1002/qj.473 